\title{
THE PHYSICAL DEVELOPMENT OF TUBERCULOUS CHILDREN *
}

\author{
M. L. BLATT, M.D. \\ Assistant Professor of Pediatrics, University of Illinois College of Medicine; \\ Attending Pediatrician, Cook County Hospital \\ CHICAgo
}

Deficiency in body weight is generally recognized as one of the important early symptoms of tuberculosis. In adults this is frequently synchronous with the appearance of focal symptoms. In childhood, focal symptoms play so unimportant a rôle in the early differential diagnosis of tuberculosis, and are so lacking in pathognomonic features, that it seems necessary to determine whether deficiency in weight can be considered of value.

Two groups of children form the basis of this study: the first group, those of nontuberculous parentage, who were themselves either without any symptoms suggestive of tuberculosis, or who had symptoms and were negative to tuberculin tests. This constituted the control group (614 children). This series was observed in the pediatric department of the West Side Jewish Aid Dispensary. The second group, comprising 508 patients, was observed in the course of a number of years at the West Side Jewish Aid Branch of the Municipal Tuberculosis Sanitarium. These children came under observation as the children of tuberculous parentage, as children suspected of tuberculosis because of poor physical condition, or referred to the tuberculosis department from the pediatric dispensary after a positive diagnosis had been made.

No attempt was made to differentiate between the various types and stages of tuberculous infection. Personal observation leads me to believe that tuberculosis in early childhood remains an acute disease over an undetermined number of years, and that there is no method which enables one to determine the activity or quiescence of the infection. The diagnosis of the tuberculosis was based on physical findings and the von Pirquet test. The physical findings were very largely those of bronchial and hilus gland involvement. This group of children, under observation for several years, was studied to see if a conclusion could be drawn as to the effect of a recognized tuberculous infection on the height and weight.

The majority of cases were tested with both bovine and human tuberculin. No case was recorded as positive unless it gave the characteristic reaction to tuberculin. This point is mentioned because it is

* Received for publication, Dec. 11, 1920.

*Read before the joint meeting of the Chicago Medical Society and Chicago Pediatric Society, Nov. 17, 1920. 
my opinion that physical findings are not sufficient grounds for the diagnosis of tuberculosis in the absence of the positive tuberculin reaction (except when overwhelming infections with the tubercle bacillus are present, or the acute exanthemata, especially measles and scarlatina. It is also likely to be negative in pertussis and pneumonia). The basic clinical work of von Pirquet, the observations of Franz Hamburger, and the combined clinical and pathological study made by Gohn, prove conclusively that the infection may be demonstrated postmortem in cases in which the cutaneous test was positive during life.

In order to establish a foundation of normal height and weight of children in this district, a control group was used. The comparison of this group with the ideal weights given by the Children's Bureau of the Department of Labor, shows clearly the necessity for comparing special groups of children with like groups from the same social status, living in a similar environment. Only by such comparison is it possible to minimize errors in deduction.

I will first consider the statistics (Tables 1 to 6 ) which have to do with the initial height and weight of the boys and girls in the three groups, namely, Children's Bureau, Control and Tuberculous. From these tables, charts were plotted indicating graphically the measurements at half year periods, from 1 to 14 years, inclusive.

The tuberculous and control curves do not rise evenly like those of the Children's Bureau. The reason for this is that there was not the same number of observations in each age period, and the total number in each series was relatively small (tuberculous 508, control 614) in comparison with the thousands of children observed by the Children's Bureau.

It also appears more than a coincidence that the depressions and elevations of the tuberculous and control curves should so closely correspond as they do. The explanation seems to be that the children of these series came from a small district in which hygienic, dietetic, economic, and social conditions were decidedly adverse, so that while there is a well marked difference in their heights and weights, nevertheless their measurements rose and fell in rather parallel fashion.

The features that have been especially noted are: (1) The number of points at which the control and tuberculous lines have risen above the Bureau line, indicating the number of age groups that have been normal in the available statistics; (2) the number of individuals represented by these normal age groups, and (3) the percentage of the series that came up to the Bureau standard.

These three observations are represented in a column, indicative of the percentage of normality of the control and tuberculous groups in comparison with the Children's Bureau standard, represented as 100 per cent. 
TABlE 1.-Height and Weight of Tuberculous Boys (256)

\begin{tabular}{|c|c|c|c|c|c|c|c|c|}
\hline \multirow{2}{*}{$\begin{array}{c}\text { Age. } \\
\text { Years }\end{array}$} & \multirow{2}{*}{$\begin{array}{l}\text { Num- } \\
\text { ber of }\end{array}$} & \multicolumn{2}{|c|}{$\begin{array}{l}\text { Initial Measure- } \\
\text { ments }\end{array}$} & \multirow{2}{*}{$\begin{array}{c}\text { Period } \\
\text { of } \\
\text { Observa- } \\
\text { tion in }\end{array}$} & \multicolumn{2}{|c|}{$\begin{array}{c}\text { Average Gain in } \\
\text { This Period }\end{array}$} & \multicolumn{2}{|c|}{$\begin{array}{c}\text { Average Gain per Year } \\
\text { While Observed }\end{array}$} \\
\hline & & $\begin{array}{c}\text { Height, } \\
\text { Inches }\end{array}$ & $\begin{array}{l}\text { Weight. } \\
\text { Pounds }\end{array}$ & & $\begin{array}{l}\text { Height, } \\
\text { Inches }\end{array}$ & $\begin{array}{l}\text { Weight, } \\
\text { Pounds }\end{array}$ & $\begin{array}{c}\text { Height, } \\
\text { Inches }\end{array}$ & $\begin{array}{l}\text { Weight, } \\
\text { Pounds }\end{array}$ \\
\hline $\begin{array}{l}1 \\
11 / 2 \\
2 \\
21 / 2 \\
3 \\
31 / 2 \\
4 \\
41 / 2 \\
5 \\
51 / 2 \\
6 \\
61 / 2 \\
7 \\
71 / 2 \\
8 \\
816 \\
9 \\
91 / 2 \\
10 \\
101 / 2 \\
11\end{array}$ & $\begin{array}{r}1 \\
2 \\
6 \\
6 \\
4 \\
1 \\
12 \\
2 \\
15 \\
7 \\
11 \\
2 \\
30 \\
8 \\
29 \\
2 \\
24 \\
3 \\
28 \\
1 \\
12\end{array}$ & $\begin{array}{c}\ldots . . \\
\dddot{33.1} \\
35.7 \\
37.0 \\
\dddot{38.2} \\
40.3 \\
41.0 \\
43.0 \\
44.8 \\
\dddot{4} .1 \\
45.0 \\
48.1 \\
45.0 \\
49.2 \\
41.6 \\
52.2 \\
\ldots \ldots .0 \\
51.9\end{array}$ & $\begin{array}{l}20.2 \\
22.4 \\
24.6 \\
28.7 \\
31.6 \\
34.7 \\
34.5 \\
31.5 \\
38.4 \\
39.1 \\
41.6 \\
43.3 \\
45.9 \\
47.9 \\
52.9 \\
50.7 \\
57.2 \\
56.6 \\
58.1 \\
67.5 \\
61.1\end{array}$ & $\begin{array}{l}35.0 \\
25.0 \\
30.8 \\
27.6 \\
50.0 \\
51.0 \\
29.0 \\
14.0 \\
35.3 \\
36.0 \\
35.1 \\
51.5 \\
34.3 \\
25.7 \\
31.7 \\
15.0 \\
24.5 \\
21.3 \\
28.0 \\
29.0 \\
17.9\end{array}$ & $\begin{array}{r}\ldots . . \\
\dddot{7.5} \\
7.4 \\
10.2 \\
\dddot{7.0} \\
1.7 \\
6.8 \\
4.8 \\
5.6 \\
\dddot{5} .5 \\
4.3 \\
4.5 \\
3.5 \\
4.6 \\
10.1 \\
4.6 \\
\dddot{4} .6 \\
4.3\end{array}$ & $\begin{array}{r}15.8 \\
9.5 \\
10.2 \\
9.9 \\
20.4 \\
16.5 \\
10.3 \\
30 \\
14.6 \\
9.8 \\
14.0 \\
21.2 \\
16.5 \\
12.8 \\
19.2 \\
24.5 \\
130 \\
12.5 \\
20.9 \\
23.5 \\
12.2\end{array}$ & $\begin{array}{r}\ldots . . \\
\dddot{2.3} \\
3.2 \\
2.4 \\
\dddot{3} .0 \\
1.4 \\
2.2 \\
1.6 \\
1.9 \\
\dddot{1} .9 \\
2.0 \\
1.3 \\
\dddot{2} .9 \\
5.6 \\
1.9 \\
\dddot{2} .8\end{array}$ & $\begin{array}{r}5.4 \\
4.5 \\
3.9 \\
4.3 \\
4.8 \\
3.8 \\
4.1 \\
2.5 \\
4.9 \\
3.2 \\
4.7 \\
4.9 \\
5.8 \\
5.9 \\
7.2 \\
19.6 \\
6.3 \\
7.0 \\
8.9 \\
9.7 \\
8.1\end{array}$ \\
\hline $\begin{array}{l}11^{1 / 2} \\
12 \\
12^{1 / 2} \\
13 \\
13^{1 / 2} \\
14\end{array}$ & $\begin{array}{r}\ddot{17} \\
7 \\
13 \\
3 \\
10\end{array}$ & $\begin{array}{l}3 . . . \\
54.0 \\
53.8 \\
55.1 \\
58.1 \\
56.7\end{array}$ & $\begin{array}{l}\ddot{68.7} \\
73.3 \\
75.6 \\
92.5 \\
82.2\end{array}$ & $\begin{array}{l}17.0 \\
14.0 \\
19.7 \\
25.0 \\
22.5\end{array}$ & $\begin{array}{l}\dddot{4.2} \\
6.3 \\
4.1 \\
8.0 \\
5.2\end{array}$ & $\begin{array}{l}\ddot{20.5} \\
12.3 \\
14.2 \\
27.9 \\
14.3\end{array}$ & $\begin{array}{l}\ddot{2.9} \\
5.3 \\
2.4 \\
3.8 \\
2.7\end{array}$ & $\begin{array}{r}7 . . \\
14.4 \\
10.5 \\
8.6 \\
13.3 \\
7.6\end{array}$ \\
\hline
\end{tabular}

TABLE 2.-Height and Weight of Tuberculous Girls (252)

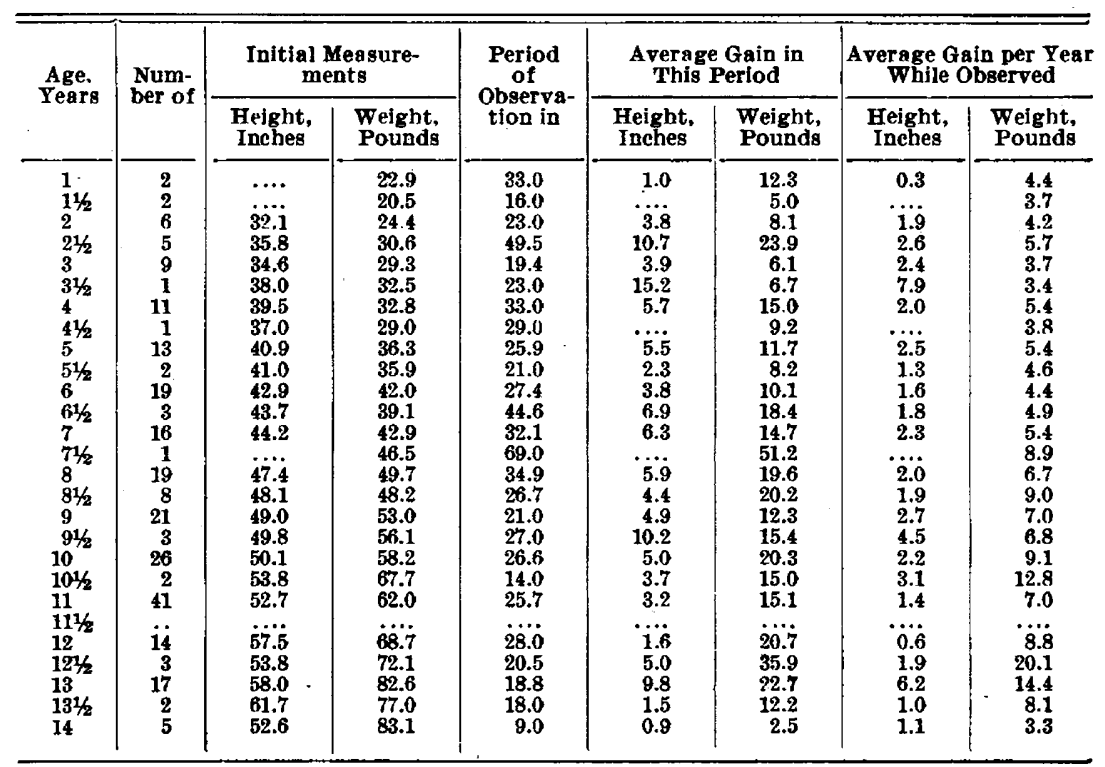


TABLE 3.-Height and Weight of Control Boys (277)

\begin{tabular}{|c|c|c|c|c|c|}
\hline \multirow{2}{*}{$\begin{array}{l}\text { Age, } \\
\text { Years }\end{array}$} & \multirow{2}{*}{$\underset{\text { Cases }}{\text { Number of }}$} & \multicolumn{2}{|c|}{ Initial Measurements } & \multicolumn{2}{|c|}{ Gain per Year* } \\
\hline & & $\begin{array}{l}\text { Height, } \\
\text { Inches }\end{array}$ & $\begin{array}{l}\text { Weight, } \\
\text { Pounds }\end{array}$ & $\begin{array}{c}\text { Height, } \\
\text { Inches }\end{array}$ & $\begin{array}{l}\text { Weight, } \\
\text { Pounds }\end{array}$ \\
\hline $\begin{array}{l}1 \\
11 / 2 \\
2 \\
21 / 2 \\
3 \\
31 / 2 \\
4 \\
41 / 2 \\
5 \\
51 / 2 \\
6 \\
61 / 2 \\
7 \\
71 / 2 \\
8 \\
81 / 2 \\
9 \\
91 / 2 \\
10 \\
101 / 2 \\
11 \\
111 / 2 \\
12 \\
121 / 2 \\
13 \\
131 / 2 \\
14\end{array}$ & $\begin{array}{r}9 \\
25 \\
13 \\
4 \\
20 \\
12 \\
17 \\
5 \\
20 \\
7 \\
17 \\
4 \\
19 \\
1 \\
19 \\
4 \\
16 \\
4 \\
11 \\
4 \\
12 \\
1 \\
6 \\
30 \\
20 \\
1 \\
6\end{array}$ & $\begin{array}{l}22.4 \\
33.0 \\
35.2 \\
35.4 \\
37.0 \\
36.6 \\
41.0 \\
40.4 \\
41.1 \\
42.6 \\
42.2 \\
45.0 \\
48.0 \\
47.0 \\
48.0 \\
49.5 \\
48.5 \\
49.4 \\
53.5 \\
52.6 \\
53.0 \\
55.8 \\
.57 .0 \\
59.0 \\
58.5\end{array}$ & $\begin{array}{l}16.3 \\
23.2 \\
30.1 \\
28.0 \\
30.0 \\
30.5 \\
34.0 \\
36.4 \\
37.6 \\
37.7 \\
41.1 \\
42.0 \\
44.0 \\
49.5 \\
49.7 \\
49.0 \\
54.5 \\
54.7 \\
54.7 \\
74.0 \\
63.6 \\
72.0 \\
80.8 \\
\dddot{77.6} \\
94.5 \\
88.3\end{array}$ & $\begin{array}{c}\ldots . . \\
\dddot{3.1} \\
2.2 \\
2.3 \\
2.4 \\
3.0 \\
2.7 \\
2.3 \\
2.3 \\
2.3 \\
1.9 \\
1.5 \\
0.7 \\
2.4 \\
0.8 \\
1.3 \\
\ldots 2.5 \\
1.9 \\
0.9 \\
\ldots .3 \\
2.2 \\
2.2 \\
\ldots . . \\
\ldots . . \\
\ldots . .\end{array}$ & $\begin{array}{c}3.5 \\
2.4 \\
3.9 \\
3.6 \\
4.4 \\
3.6 \\
2.1 \\
4.1 \\
3.7 \\
4.5 \\
6.4 \\
4.8 \\
2.4 \\
9.1 \\
4.5 \\
4.4 \\
7.3 \\
9.8 \\
1.4 \\
\ldots . . \\
\ldots . .6 \\
9.6 \\
\ldots . . \\
\ldots \ldots . \\
\ldots . . \\
\ldots . .\end{array}$ \\
\hline
\end{tabular}

- This flgure was computed by dividing the average gain, for a period equal in length to that of the tuberculous groups, by 12 .

table 4.-Height and Weight of Control Girls (337)

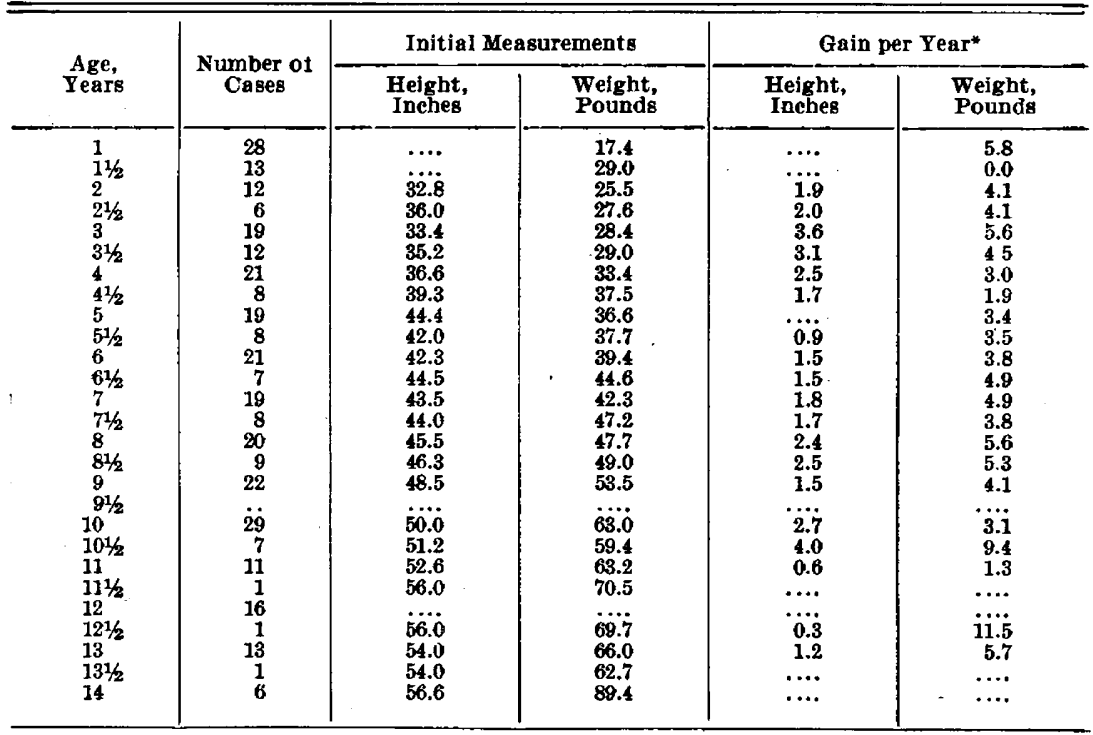

* This figure was computed by dividing the average gain, for a period equal in length to that of the tuberculous groups, by 12. 
table 5.-Weight and Height of Bureau of Children-Boys

\begin{tabular}{|c|c|c|c|c|}
\hline \multirow{2}{*}{$\begin{array}{l}\text { Age, } \\
\text { Years }\end{array}$} & \multicolumn{2}{|c|}{ Measurements } & \multicolumn{2}{|c|}{ Gain per Year (As in Table 3) } \\
\hline & $\begin{array}{l}\text { Height, } \\
\text { Inches }\end{array}$ & $\begin{array}{l}\text { Weight, } \\
\text { Pounds }\end{array}$ & $\begin{array}{l}\text { Height, } \\
\text { Inches }\end{array}$ & $\begin{array}{l}\text { Weight, } \\
\text { Pounds }\end{array}$ \\
\hline $\begin{array}{l}1 \\
11 / 2 \\
2 \\
21 / 2 \\
3 \\
31 / 2 \\
4 \\
41 / 2 \\
5 \\
51 / 2 \\
6 \\
61 / 2 \\
7 \\
71 / 2 \\
8 \\
81 / 2 \\
9 \\
91 / 2 \\
10 \\
101 / 2 \\
11 \\
111 / 2 \\
12 \\
121 / 2 \\
13 \\
131 / 2 \\
14\end{array}$ & $\begin{array}{l}29.3 \\
31.7 \\
3.7 \\
35.3 \\
37.1 \\
38.6 \\
34.5 \\
40.5 \\
41.6 \\
42.7 \\
43.8 \\
44.7 \\
45.7 \\
46.7 \\
47.8 \\
48.7 \\
49.7 \\
50.7 \\
51.7 \\
52.3 \\
53.3 \\
54.2 \\
55.1 \\
56.1 \\
57.2 \\
58.5 \\
59.9\end{array}$ & $\begin{array}{l}21.8 \\
24.6 \\
27.1 \\
29.5 \\
32.2 \\
33.7 \\
35.8 \\
38.4 \\
41.1 \\
43.1 \\
45.2 \\
47.1 \\
49.1 \\
51.5 \\
53.9 \\
56.9 \\
59.2 \\
62.2 \\
65.3 \\
67.7 \\
70.2 \\
73.5 \\
76.9 \\
80.8 \\
84.8 \\
89.8 \\
84.9\end{array}$ & $\begin{array}{l}3.3 \\
3.3 \\
2.6 \\
2.4 \\
2.0 \\
2.0 \\
2.1 \\
2.1 \\
2.1 \\
2.0 \\
2.0 \\
2.0 \\
1.9 \\
2.0 \\
1.8 \\
2.0 \\
1.7 \\
1.6 \\
1.7 \\
1.9 \\
1.8 \\
\dddot{20} .3 \\
2.3 \\
2.6 \\
2.5 \\
2.8\end{array}$ & $\begin{array}{r}4.7 \\
4.3 \\
4.4 \\
4.4 \\
4.0 \\
4.4 \\
4.5 \\
4.6 \\
4.3 \\
4.4 \\
4.7 \\
5.6 \\
5.3 \\
5.4 \\
5.5 \\
5.7 \\
5.3 \\
5.4 \\
6.0 \\
7.0 \\
7.0 \\
\dddot{9} .1 \\
9.1 \\
11.1 \\
12.0 \\
12.4\end{array}$ \\
\hline
\end{tabular}

table 6.-Weight and Height of Bureau of Children-Girls

\begin{tabular}{|c|c|c|c|c|}
\hline \multirow{2}{*}{$\begin{array}{l}\text { Age, } \\
\text { Years }\end{array}$} & \multicolumn{2}{|c|}{ Measurements } & \multicolumn{2}{|c|}{ Gain per Year (As in Table 3) } \\
\hline & $\begin{array}{l}\text { Height, } \\
\text { Inches }\end{array}$ & $\begin{array}{l}\text { Weight, } \\
\text { Pounds }\end{array}$ & $\begin{array}{l}\text { Height, } \\
\text { Inches }\end{array}$ & $\begin{array}{l}\text { Weight, } \\
\text { Pounds }\end{array}$ \\
\hline $\begin{array}{l}1 \\
11 / 2 \\
2 \\
21 / 2 \\
3 \\
31 / 2 \\
41 / 2 \\
41 / 2 \\
5 \\
51 / 2 \\
6 \\
61 / 2 \\
7 \\
71 / 2 \\
8 \\
81 / 2 \\
9 \\
91 / 2 \\
10 \\
101 / 2 \\
11 \\
111 / 2 \\
12 \\
121 / 2 \\
13 \\
131 / 2 \\
14\end{array}$ & $\begin{array}{l}28.8 \\
31.1 \\
33.3 \\
34.8 \\
36.7 \\
38.0 \\
39.0 \\
40.1 \\
41.3 \\
42.3 \\
43.4 \\
44.4 \\
45.5 \\
46.5 \\
47.6 \\
48.5 \\
49.4 \\
50.3 \\
51.3 \\
52.3 \\
53.4 \\
54.6 \\
55.9 \\
57.0 \\
58.2 \\
59.0 \\
59.9\end{array}$ & $\begin{array}{l}20.7 \\
23.3 \\
26.3 \\
28.2 \\
30.5 \\
32.5 \\
33.7 \\
36.7 \\
39.7 \\
41.5 \\
43.3 \\
45.4 \\
47.5 \\
49.7 \\
52.0 \\
54.5 \\
57.1 \\
58.7 \\
62.4 \\
65.6 \\
68.8 \\
73.5 \\
78.3 \\
83.5 \\
88.7 \\
93.5 \\
98.4\end{array}$ & $\begin{array}{l}3.3 \\
3.6 \\
2.8 \\
2.3 \\
2.1 \\
2.2 \\
2.1 \\
2.2 \\
2.1 \\
2.1 \\
2.0 \\
2.0 \\
1.9 \\
2.1 \\
1.8 \\
1.9 \\
1.9 \\
2.1 \\
1.9 \\
2.3 \\
2.3 \\
7.8 \\
1.8 \\
1.8 \\
1.4 \\
1.4 \\
1.2\end{array}$ & $\begin{array}{c}3.8 \\
5.0 \\
3.7 \\
4.1 \\
.3 .8 \\
4.6 \\
4.6 \\
4.4 \\
5.7 \\
3.6 \\
3.0 \\
5.6 \\
4.8 \\
7.1 \\
6.1 \\
6.2 \\
5.7 \\
7.1 \\
7.3 \\
8.2 \\
10.0 \\
7.0 .7 \\
10.7 \\
9.4 \\
8.6 \\
8.3 \\
7.5\end{array}$ \\
\hline
\end{tabular}


A study of the heights of boys shows that whereas seven of twentyone tuberculous groups were normal in comparison with the Children's Bureau standard, the boys of the control series were normal in only five of twenty-five age periods. Furthermore, the number of individuals in these normal groups was 112 of 256 for tuberculous boys, or 43.75 per cent., but only 17 of 277 for control boys, or 6.13 per cent. In other words, the tuberculous males reached or surpassed the Bureau requirements for height seven times as often as those of the control series.

The figures for the girls of the tuberculous and control groups are less striking. The tuberculous girls were normal in six of twenty-three age periods while the control girls equalled the standard in only four of twenty-three age groups. The percentage of normality for these groups was 13.88 ( 35 of 252 ) for the tuberculous girls and 9.79 ( 33 of 337 ) for the controls. We note a definite though less marked superiority of the tuberculous females.

The tuberculous boys were normal in only two of twenty-six age periods, while the males of the control series were up to par in four of twenty-six groups. There were only four of 256 , or 1.56 per cent., tuberculous boys who were of normal weight. However, twenty-four of 277 ( 8.66 per cent.) control boys reached the Bureau standard, almost five and one-half times as often as the members of the tuberculous series.

A consideration of these results shows that the type of boy in the tuberculous group was one whose height more frequently reached that of the Children's Bureau standard than did the control boy, but whose weight far less often was normal.

As for the weights of girls, it is apparent that three of twenty-six tuberculous groups were normal, while in the control group three of twenty-five were normal. With reference to the individual cases it is shown that 14.83 per cent. ( 50 of 337 ) of the control girls attained the Bureau standard, but only 1.98 per cent. ( 5 of 252) of the tuberculous series attained that standard. The control girls were thus strikingly more often of normal weight than the tuberculous girls $(7: 1)$.

Here, as with the boys, the tuberculous girl is comparatively taller but of a lesser weight than her sister of the control series. Both are much below the Children's Bureau standard.

With reference to height, the tuberculous boys were normal in 150 of 256 cases, or 58.59 per cent., as compared with 43.75 per cent. ( 112 or 256) of the averages for age groups. The control males were equal to the bureau norm in 88 or 243 observations, or 36.21 per cent., a figure which is much higher than the 6.13 per cent. (17 of 277) for height. 


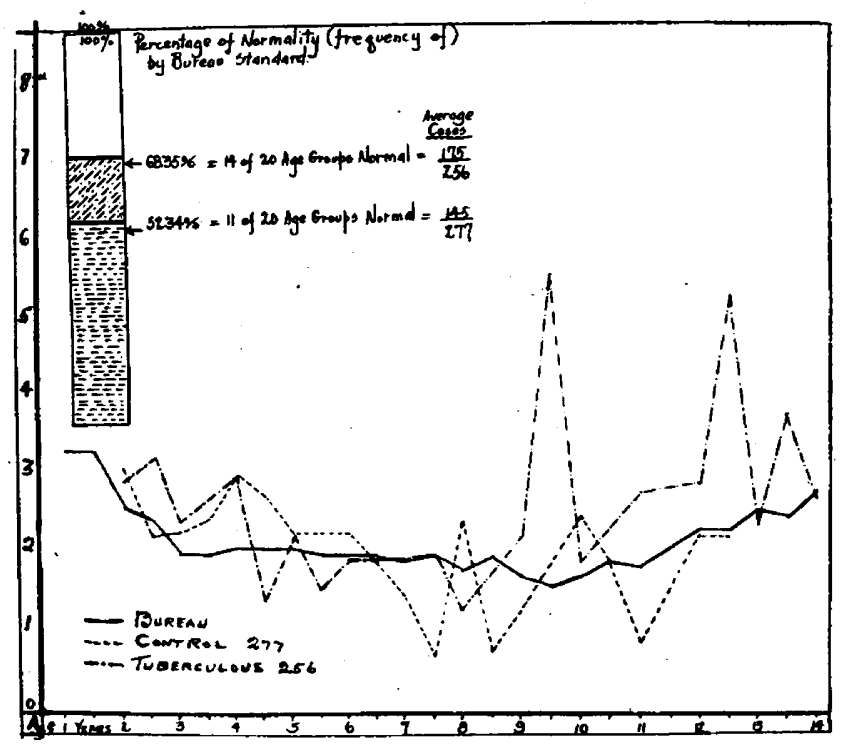

Fig. 1.-Average gain in inches of different groups of boys per year.

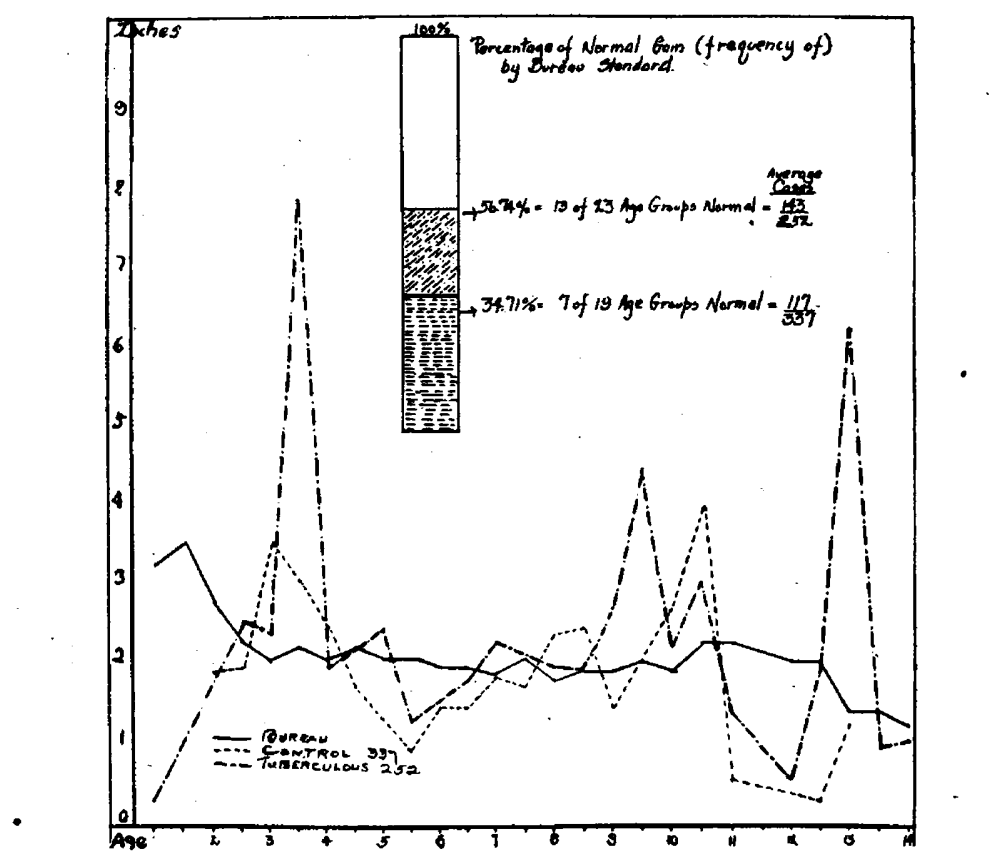

Fig. 2.-Average gain in inches of different groups of girls per year. 
The weight of the tuberculous boys reached the standard in 11.32 per cent. (29 of 256) as compared with the 1.56 per cent. (4 of 256) of the averages for age groups. Similarly, the percentage of normality is higher for control boys, 25.52 per cent. ( 74 of 277 ).

However, the fact remains that the tuberculous boys were more often of normal height than the controls, but were not as frequently of the normal weight.

As for the height and weight of girls, the tuberculous girls were of normal height in 58.29 per cent. (147 of 252) in contrast to 33.22 per cent. (98 of 295) for the controls.

With reference to weight, however the tuberculous girls were normal in only 1.98 per cent., and the controls in 14.83 per cent. Our individual observations, instead of average, indicate that the tuberculous girls were normal in 26.19 per cent. of the cases ( 66 of 252) while the control girls were slightly below this percentage, 23.69 per cent. ( 80 of 336 observations). The explanation for the difference lies in the fact that a large number of the individuals in the subnormal average age groups were equal to the Bureau norm.

The heights and weights of the boys and girls were added to give a composite. The tuberculous children were up to the standard in height in 58.47 per cent. of the cases (297 of 508), and the controls in 35.58 per cent. (186 of 538), so that the tuberculous child in individual instances attained the Children's Bureau norm, 22.89 per cent. (58.4735.58), more frequently than the control.

However, the tuberculous child was less often of normal weight, 18.71 per cent. normality (95 of 508), as contrasted with 25.05 per cent. (154 of 615) for the control individual.

My conclusion as to tuberculosis in childhood is that given a group of children below the norm in height and weight, the tuberculous child will more frequently appear to be of normal height, but far less often of normal weight. The tuberculous individual is often seen as the lanky child.

This concludes the observations on the initial heights and weights of the groups.

Tables 1 and 2 show the average length of time of observation in months for the various age groups. The minimum average period for boys was 14 months, and the maximum 51.5 months: for girls the minimum was nine months, and the maximum 69 months. The curves for control and Bureau were secured by calculating what these groups would have gained per year had they been watched for a period equal to that over which the tuberculous children were observed. For example: The height of a Bureau boy of three years is 37.1 inches. If this child had been observed for 50 months, as was the tuberculous boy of the 


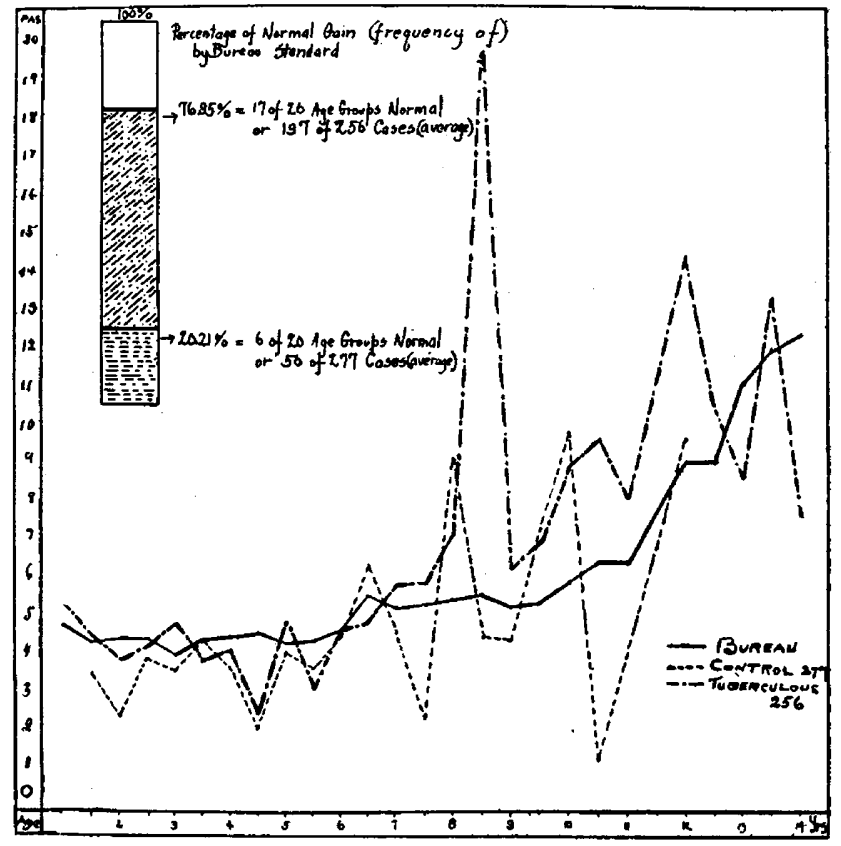

Fig. 3.-Average gain in pounds of different groups of boys per year.

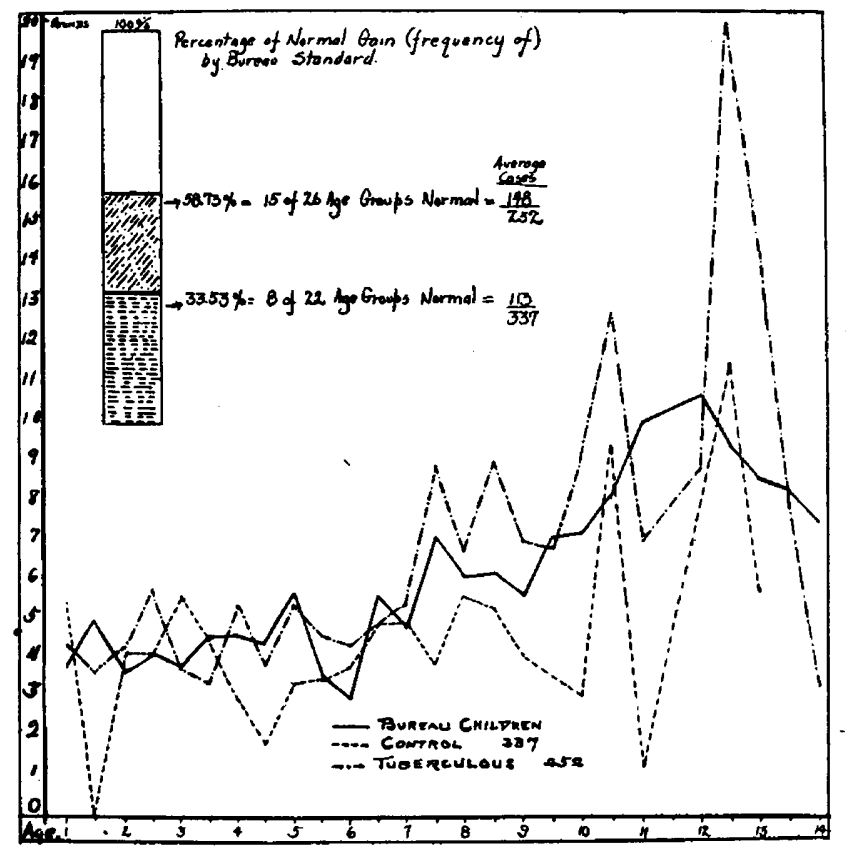

Fig. 4.-Average gain in pounds of different groups of girls per year. 
corresponding group, his height would have been 45.7 inches, a gain of 8.6 inches in this period of $42 / 12$ years. His gain for a year would have been $12 / 50$ of 8.6 inches, or 2.0 plus inches. In Chart 1 this figure was plotted. Similarly the gain was secured for other periods of the Bureau and the control series and plotted. With the Bureau curve as the standard the relative average gains of the tuberculous and control groups were studied. The tuberculous curve stands well above the control and the Bureau lines. The essential point to me appears to be how many of the tubercu'ous and control groups attained the Bureau norm.

Chart 1 shows the average gain in inches per year of boys in the three series. In fourteen of twenty age periods, the tuberculous boys crosses the curve of the Bureau standard, while eleven of twenty of the controls did likewise. These groups represent 175 of 256 tuberculous males, or 68.35 per cent. gained as well or better than the Bureau standard; while a smaller number, 145 of 277 control boys, representing 52.34 per cent. reached or passed the norm. Thus it is apparent that the tuberculous boys attained the standard more often than the control boys.

Chart 2 indicates the comparative average gain per year in height of the girls of the three series. In thirteen of twenty-three age periods the tuberculous girls attained the norm (56.00 per cent.) while in seven of nineteen ( 37.00 per cent.) the control females were up to par. More than half of the tuberculous girls equalled or surpassed the Bureau standard, 143 of 252 or 56.74 per cent. In contrast, the control girls were normal in height gain in 34.71 per cent., 117 of 337 cases.

Thus the tuberculous girls, even as the boys, equalled the Bureau gain more frequently than the control. It is interesting to note that in the very much undernourished control and tuberculous series the boys gained uniformly more normally than the corresponding girls. This fact is in accordance with the common observation in normal children, that on the whole boys gain better and are taller than girls.

Chart 3 demonstrates the remarkable better gain of the tuberculous boys over the control series. In 76.95 per cent. of the cases ( 197 of 256) and in seventeen of twenty-six age groups the tuberculous males attained the standard weight gain. The control males were up to par in only six of twenty age groups, 20.21 per cent. for 50 of 277 cases. As for degree of pound gain, the tuberculous line rises markedly after the age of seven.

The tuberculous girls (Chart 4) did not as frequently attain the Bureau weight gain as did their brothers. In fifteen of twenty-six age groups there were 148 normals of 252 (58.73 per cent.) while the controls crossed the norm in eight of twenty-two age groups for a total of 113 of 337 observations, or 33.53 per cent. The tuberculous girl 
gained in weight normally in 25.20 per cent. more instances. Here likewise the degree of weight gain is very marked from the age of seven on, in the tuberculous series.

The superiority in gain in height and weight per year of the tuberculous series has been plotted in Chart 5. The frequency of normal gain in height per year of the tuberculous child was 62.59 per cent. ( 318 and 508 observations) as contrasted with 42.67 per cent. (262 of 614 observations) for the control child. In 67.91 per cent. of the cases ( 345 of 508 ) the tuberculous child attained the Children's Bureau standard, while the control child did as well in but 27.52 per cent. (169 of 614 ).

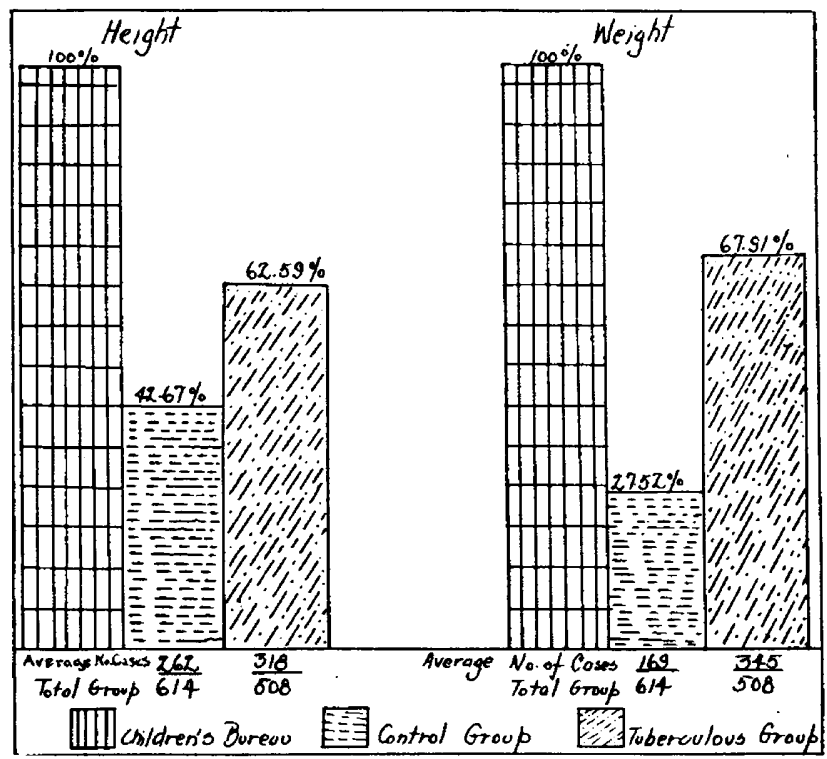

Fig. 5.-Composite of boys and girls. The percentage of normal gain per year of observation in comparison with the children's bureau standard.

\section{CONCLUSIONS}

1. Using height and weight as the basis of comparison, tuberculous children more frequently attained the normal standard of gain than those of the control series.

2. Neither the entire tuberculous nor control series reached the Children's Bureau standard, represented as 100 per cent, although the tuberculous group more frequently approached it.

3. The superiority of the tuberculous over the control series in gain, I believe to be dependent on the improvement in sanitation, food, and the removal of defects.

4. The child with hilous or tracheobronchial gland tuberculosis in a group of children under-height and under-weight, when properly treated, will more often be the one to attain the normal gain. This observation, according to my experience, is equally applicable to cases seen in private practice. 